\author{
Agata GEMZIK-SALWACH ${ }^{1}$ \\ Pawel PERZ ${ }^{2}$
}

\title{
MACROECONOMIC CONSEQUENCES OF NEW PRUDENTIAL REGULATION IN THE BANKING SECTOR
}

\begin{abstract}
This article presents the impact of new prudential regulations for banking sector and their implications for GDP growth rate. Amongst large numbers of new financial regulations that have been created in recent years, the impacts of Basel III and CDR IV/CRR was chosen for analysis. This article was created for reviewing purposing. The aim of the paper is to create a structured section of macroeconomic effects of Basel III (CRD IV/CRR). So far, the results of researching the effects of the changes on the economy and the banking system analyzed by different institutions - have led to different conclusions, which justifies the need to collect and compare these results. However, it must be noted that conducting such studies is difficult due to various assumptions that are implemented. The main objective of paper was to assess the impact of new prudential regulations for banking sector. Furthermore, it discusses the channels through which changes in regulations translate into economic growth and other macroeconomic indicators. Additionally, an analysis of the macroeconomic impact of these changes in relation to the economies of the world and domestic market was conducted. The results obtained lead to conclusions that the consequences of new regulations will lead to slight decline in future growth of economy. Therefore, there are questions which arise regarding the desired degree for regulation, its scope, scale, and time period that the standards should be maintained.
\end{abstract}

Keywords: banking sector, economic growth, Basle III, capital and liquidity regulations.

\section{INTRODUCTION}

The global financial crisis that has taken place in recent years has resulted in a threat to the security of the entire financial system. In order to avoid errors so far banking supervisory authorities introduced a number of new regulations aimed to increase the safety of banks, as an institution of public trust ${ }^{3}$. These procedures have been forced by the dynamic changes taking place in the area of risk in this market ${ }^{4}$. On the one hand, the new prudential standards were introduced to support the safety of banks. The regulatory projects that were introduced in the banking system are geared primarily to reduce the risks in banks. The introduction of new

\footnotetext{
${ }^{1}$ Agata Gemzik-Salwach, PhD, University of Information Technology and Management in Rzeszow

${ }^{2}$ Paweł Perz, PhD, Eng., Rzeszow University of Technology, ul. Powstańców Warszawy 8, 35-959 Rzeszów, (corresponding author) e-mail: pperz@prz.edu.pl

${ }^{3}$ K. Szymański, Konsekwencje kryzysu zadtużenia w strefie euro dla europejskiego i polskiego sektora bankowego, referat wprowadzający Instytutu Badań nad Gospodarką Rynkową do e-debaty, 2011.

${ }^{4}$ M. Olszak, Polityka ostrożnościowa w ujęciu makro, „Problemy Zarządzania” 2012/4, p. 8.
} 
capital requirements should help to increase the solvency of financial institutions, but at the same time to increase interdependence occurring in the banking system ${ }^{5}$. On the other hand, those new regulations impose stricter prudential standards, which are very difficult to fulfill and may lead to limiting the number of customers, which will be able to access to the credit. There is a real danger that will lead to a decline in economic growth.

In the interest of supervisors and individual economies it is to create such regulatory standards that will affect not only the strengthened stability of financial systems but also on the development of the banking system and stimulation of economic growth. The question is whether it is possible to reconcile these two objectives. Therefore, an impression arises that the developed regulation are mainly a response to financial crisis and unilaterally set for prudential purposes. There is a serious danger that the proposed solutions will be contributed to the creation of new, threats which have low researches conducted.

This article is for reviewing purposes. Its aim is to create a structured section of macroeconomic effects of Basel III (CRD IV/CRR). For analysis a study was conducted, where the main focuses was put on the attempts to access the impact of new prudential regulations for the development of the banking sector and their implications for economic growth. In relation to the objectives, the answers were searched for the following research problems:

Q1: What goals were accompanied by the introduction of the new regulations?

Q2: What are the impacting channels of regulatory changes on economic growth?

Q3: What will be the macroeconomic effects of introducing new regulations in the banking system?

These issues have fundamental importance for responding to a question about the real consequences of introducing new prudential standards. They allow verifying of stereotypical beliefs about the need to introduce new higher and stricter financial regulations. It is necessary to find a balance between the dangers of under regulating, and the overregulating the banking system $^{6}$. Amongst large numbers of new financial regulations that were created in recent years, the impacts of Basel III and CDR IV/CRR was chosen for analysis. The analysis focuses on the macroeconomic effects of new regulations, deliberately excluding the impact of these changes on the size of the indicators reflecting the situation in the banks. Moreover, these changes have also been indirectly included in this study.

\section{MAIN CHANGES IN BASEL III REGULATIONS AND OBJECTIVES ASSOCI- ATED WITH THEIR OCCURRENCE}

Changes in regulation of capital and liquidity in the banking sector are presented in the documents of the Basel Committee by banking supervision ${ }^{7}$. In Poland, the implementation of these guidelines will take place through establishment on the basis of EU regulations: Package

\footnotetext{
${ }^{5}$ European Commission, European Financial Stability and Integration, Brussels 2014.

${ }^{6}$ European Banking Federation, Principles for a Successful Future of Banking in Europe, Brussels 2010.

${ }^{7}$ Bank for International Settlements, Basel III: A Global Regulatory Framework for More Resilient Banks and Banking Systems - Revised Version, Basel 2011-2013.
} 
CRD IV/CRR, Directive 2013/36 / EU and Regulation of the European Parliament and Council Regulation (EU) No 575/2013.The most important new solutions include:

1. Clarification of the concept of equity, by describing their categories and improving their quality - the new definition of own funds have 2 categories: Tier 1 primary funds that are used to cover the losses from the normal courses of business and Tier 2 - supplementary funds, which are used to cover losses within bankruptcy. Both definitions of these categories have been strengthened. In addition, the list of deductions from own funds was expanded and was permitted to reference these deductions to CET1, abandoning the ability to fulfill the requirements with respect to capital adequacy ratio by means of short-term capital (Tier 3.) The purpose of these changes was to increase the quality and transparency of the capital base of the banks.

2. Establishing quantitative liquidity standards - Basel III introduces two requirements: LCR and NSFR. LCR $^{8}$ states that every bank must maintain sufficient quality of liquid able assets to secure financing for 30 days of any problems with liquidity and is therefore designed to strengthen banks' short-term resistance to liquidity risk. ${ }^{9} \mathrm{NSFR}{ }^{10}$ ensures the long-term liquidity. Long-term assets such as; Mortgages, should be funded by liabilities with a maturity of more than one year. NSFR standard is complementary to standard LCR, together they provide shortterm and long-term liquidity ${ }^{11}$.

3. When increasing minimum capital requirements for banks - the Basel III introduces an additional capital buffer in the form of capital adequacy ratio based on core funds. In accordance, the share capital is to be the value of at least $4.5 \%$ of risk-weighted assets, which means that it has to increase my $2.5 \%$ prove the value before. This provision is designed to increase the absorption of capital by banks and at the same time increase their resilience to shocks on financial markets.

4. The introduction of new buffers (security and counter-cyclical) - means that banks will have to maintain a protective buffer capital of $2.5 \%$ of risk-weighted assets and the countercyclical buffer ranging from 0 to $2.5 \%$ of risk-weighted assets, depending on economic conditions. As in the previous case, the introduction of these buffers is to reduce banks susceptibility to external shocks ${ }^{12}$. The

\footnotetext{
${ }^{8}$ LCR is defined as the ratio of high-quality liquid assets to net inflows in the horizon of 30 days. This value should be at least $100 \%$.

${ }^{9}$ A. Gemzik-Salwach, Skutki regulacji Bazylei III dla sektora bankowego i gospodarki, “Annales Universitatis Mariae Curie-Skłodowska. Sectio H. Oeconomia” 2012, p. 200.

${ }^{10}$ NSFR is the quotient of the available resources of stable funding and the required amount of stable funding. This relationship should be a number greater than or equal to $100 \%$.

D.K. Rosati, Regulacje makroostrożnościowe a stabilność sektora bankowego, „,Bank i Kredyt” 2014, p. 392.

${ }^{12}$ K. Kochaniak, Kapitat regulacyjny sektora bankowego w Polsce na tle rozwiazań Bazylei III, ,Zeszyty Naukowe. Polskie Towarzystwo Ekonomiczne" 2011/11, p. 159-160.
} 
legitimacy of using this instrument was explained by the negative impact of banks' losses during the crisis in the sector and real sphere ${ }^{13}$.

5. Determination of leverage - has to complement the risk-based measure, which operates within the framework of Basel II. The leverage ratio will apply from 2018, until now there predictions about future intentions for couple of years, that supervisory authority will monitor it. Leverage ratio was set at a minimum of $3 \%$. The purpose of this provision is to prevent excessive leverage of financial institutions ${ }^{14}$.

Assessment of objectives of newly created regulations should be considered as reasonable and correct. The essence of the changes is that they serve to strengthen stability of financial system and its resistance to external interference. Efforts were made to ensure that the new regulations prevent errors, which are the main cause of the previous crisis, such as: insufficient capital, global assets financed by short-term sources of systemic risk - the interconnectedness and complexity of operations and the lack of systemic solutions for large institutions conducting bankruptcy ${ }^{15}$. New standards can be implemented gradually and their effects will be monitored, a target period to put them in a final version will be year 2019 .

\section{INFLUENCING CHANNELS IMPACTING REGULATIONS ON GROWTH OF ECONOMY}

Although the objectives pursued from creating new prudential standards are reasonable and logical, and are intended to secure solvency, thereby protecting customers and the banks themselves for losses or bankruptcy, their inevitable consequence of an increase in the cost of financing ${ }^{16}$. The global economy is a system of connected vessels and systematic risk, which tend to move through various channels. ${ }^{17}$ Transferring the regulatory changes on economic growth takes place mainly through the credit channel. Of all the proposed changes, the greatest impact on economic growth is the introduction of capital and liquidity standards. It is believed that stricter prudential requirements will result in increased interest rates on loans and on demand for capital. ${ }^{18}$ Increasing lending rates can be decomposed into cost of financing, risk premium, premium reflecting the market position of the bank and premium reflecting the sensitivity of the cost of capital on the volume of loans. ${ }^{19}$ As a result from increasing prices of

\footnotetext{
${ }^{13}$ H. Hannoun, The Basel III Capital Framework: A Decisive Breakthrough, Bank for International Settlements, Hong Kong 2010; Narodowy Bank Polski, Opinia NBP w sprawie dokumentu konsultacyjnego Komisji Europejskiej „Possible further changes to capital requirements directive”, Warszawa 2010.

${ }^{14}$ M. Marcinkowska, P. Wdowiński, S. Flejterski, S. Bukowski, M. Zygierewicz, Wptyw regulacji sektora bankowego na wzrost gospodarczy - wnioski dla Polski, Narodowy Bank Polski, ,Materiały i Studia”2014/305, p. 53

${ }^{15}$ E. Miklaszewska, Duże banki $w$ świetle pokryzysowej architektury regulacyjnej, [in:] Finanse $w$ niestabilnym otoczeniu - dylematy i wyzwania. Bankowość, ed. I. Pyka, J. Cichorska, Wydawnictwo Uniwersytetu Ekonomicznego w Katowicach 2012, p. 181

${ }^{16}$ J. Przychodzeń, Europejskie rynki finansowe w obliczu globalnego kryzys, „Problemy Zarządzania” 2012/4, p. 60.

${ }^{17}$ R. Karkowska, Koszty ekonomiczne ryzyka systemowego na rynku finansowym, „Problemy Zarządzania” 2012/4, p. 39.

${ }^{18}$ V. Gafrikova, R. Milic-Czerniak, Bazylea III - zmiany kapitatowe i ich konsekwencje, ,Bezpieczny Bank” 2011/4.

${ }^{19}$ Basel Committee on Banking Supervision, Results of the Comprehensive Quantitative Impact Study, Basel 2010.
} 
credits, demand for consumer loans and investment will be reduced. Consumer demand and investment demand are components of GDP, which means that a decrease in these numbers will translate into a decreasing rhythm of economic growth. In addition, changes in interest rates are affecting the value of exports and imports, prices and the value of financial assets. Decline in GDP translates into a general deterioration of the conditions for the functioning of society and leads to a further reduction in lending due to increased credit risk.

\section{IMPLICATIONS OF NEW PRUDENTIAL REGULATION IN THE BANKING SECTOR WHICH STIMULATE GROWTH IN THE WORLD}

Introduction of new prudential norms were preceded by public consultation and research studies of possible consequences. One of the first studies devoted to this subject was conducted by experts from the Basel Committee, the Banking Supervision, from European Central Bank and European Commission. ${ }^{20}$ They show that the consequences of higher capital standards and liquidity ratios translate into economic growth to some extent. It has increased from $0.3 \%$ to $2.0 \%$ due to reduced frequency and likelihood of financial crises. It is expected that the probability of financial crises will be limited in seven Member States with range of $29 \%$ to $89 \%$.The final analysis shows the advantage and benefits of the new regulations that exceed their costs. ${ }^{21}$

However, there are some doubts that Basel Committee did not estimate the exact cost of applying new regulations. Attention is drawn to the following issues: the additional capital required for global banks, too broad definition of systemically important banks, the separation of banking activities of different legal entities, however it is not excluded that the introduction of new regulations may result in further need of regulations. ${ }^{22}$

From another research from Bank for International Settlements it turns out that increasing banks' capital adequacy ratio by 1 percentage, on a constant structure of assets will result in increasing interest rates by 15 basis points. Meeting the liquidity requirements for banks leads to a further increase in interest rates by another 24 basis points. These studies were carried out on the basis of data from the period 1993-2007 with 6844 banks in 13 OECD countries. ${ }^{23}$

According to OECD, macroeconomic effects from introduction of new regulations will result in significant grow in GDP and rising unemployment level. The introduction of new standards will result in decline in GDP in the euro area over the medium term range from 0.08 to 0.23 percentage points per year.GDP of main OECD countries (United States, European area, Japan) according to calculations will decline in range of 0.05 to 0.15 percentage points. These changes are primarily due to increasing credit margins. It is expected that by 2015 ,

\footnotetext{
${ }^{20}$ Ibidem.

${ }^{21}$ Szok regulacyjny a konkurencyjność i rozwój sektora bankowego, ed. S. Kasiewicz, L. Kurkliński, Warszawski Instytut Bankowości, Warszawa 2012, p. 176.

${ }^{22}$ K. Kalicki, Wptyw Bazylei III/CRD4 na sytuację sektora bankowego, http://alterum.pl/pdf/Dr_hab_ Krzysztof_Kalicki.pdf (last viewed 19.09.2014).

${ }^{23}$ M.R. King, Mapping Capital and Liquidity Requirements to Bank Lending Spreads, "BIS Working Papers" 2010/324.
} 
lending rates will increase by 15 basis points in 2019 of OECD countries - this means an increase by 50 basis points. In general, increase in capital adequacy ratio by one percentage in the OECD countries translates into an increase in credit margins of 14.4 basis point. ${ }^{24}$ Similar conclusions were reached, by the authors of the report: Assessing the macroeconomic impact of the transition to stronger capital and liquidity requirements - Final Report, who presented the research results, with average of 97 models, including 42 models of national economies, 40 models, of International Monetary Fund and 15 models of European Central Bank and the European Commission. ${ }^{25}$. It shows that the increase in the capital adequacy ratio by 1 percentage point will translate into an increase in credit margins by 15 basis points and a decrease in the effective demand for loans by $1.89 \%$, and this translates into a decline in GDP of $0.22 \%$ after 35 quarters after conducted changes. This means limiting the annual GDP growth rate by 0.03 percentage points. The studies focus on occurrence of the factors that may mitigate the negative impact of new regulations on interest rates and economic growth. This means strengthening capital base of many banks by retaining earnings, new issues and opportunities for more efficient management of operating costs. The potential for reducing the negative effects of the new regulations is through careful cost management in banks. ${ }^{26}$ It is confirmed that the impact of new regulations on the growth of lending rates in the long term will be negligible.

Studies of relationship between Basel III and economic growth in the long term have shown that an increase in the capital adequacy ratio by 1 percentage point, GDP would decrease by $0.09 \%$ compared to the baseline scenario, and then with an increase in the demand for liquid assets by a further $0.08 \%-0.15 \%$. At the same time the forecast is to reduce the amplitude of the fluctuations in $\mathrm{GDP}^{27}$.

The Institute of International Finance estimates that in 2015 the level of GDP for the United States, European are, Japan, the UK and Switzerland would be about $3.2 \%$ lower than it would be if the new regulations were not been introduced (baseline scenario). The decrease in the level of employment in these countries rated an average of 7.5 million. The first adjusting mechanisms have to raise the level of banks' lending rates and limiting access to them. Within five years, it is expected that level of interest rates on loans will increase, in countries with 364 basis points and the appearance of an additional capital requirement at the level of $\$ 1.3$

${ }^{24}$ P. Slovik, B. Cournède, Macroeconomic Impact of Basel III, “OECD Economics Department Working Papers" 2011, s. 8-9.

${ }^{25}$ MAGG, Assessing the Macroeconomic Impact of the Transition to Stronger Capital and Liquidity Requirements Final Report, Bank for International Settlements, Basel 2010.

${ }^{26}$ D.J. Elliott, Quantifying the Effects of Lending Increased Capital Requirements, Brookings Institution_2009, www.brookings.edu/ /media/research/files/papers/2009/9/24\%20capital\%20elliott/0924_capital_elliott.pdf (last viewed 19.09.2014); idem, A Further Exploration of Bank Capita lRequirements: Effects of Competition from other Financial Sectors and Effects of Size of Bank or Borrower and of Loan Type, BrookingsInstitution 2010, http://www.brookings.edu/ /media/research/files/papers/2010/1/29\%20capital\%20elliott/0129_capital_requirement s_elliott.pdf (last viewed 19.09.2014).

${ }^{27}$ P. Angelini, L. Clerc, V. Cúrdia, L. Cambacorta, A. Gerali, A. Locarno, R. Motto, V. Roeger, S. Van den Heuvel, J. Vlček, Basel III: Long-term Impact Economic Performance and Fluctuations, "Federal Reserve Bank of New York Staff Reports” 2011, p. 485. 
billion. However, it was considered that these are the costs for short term, and longer-term changes will bring benefits to achieving financial stability. ${ }^{28}$ More detailed results of this estimation are summarized in Table 1.

Table1. Changes in GDP and employment in the global economy due to adaption of requirementsBasel III in 2015

\begin{tabular}{|l|c|c|c|}
\hline & $\begin{array}{c}\text { Change of GDP, } \\
\text { compared to the } \\
\text { baseline scenario } \\
\text { (percentage diffe- } \\
\text { rence) }\end{array}$ & $\begin{array}{c}\text { GDP growth } \\
\text { (in percentage } \\
\text { points) }\end{array}$ & $\begin{array}{c}\text { Employment } \\
\text { (in millions) }\end{array}$ \\
\hline USA & $-2,7 \%$ & $-0,6 \%$ & $-2,9$ \\
\hline European area & $-3,0 \%$ & $-0,6 \%$ & $-2,8$ \\
\hline Japan & $-4,0 \%$ & $-0,8 \%$ & $-0,5$ \\
\hline $\begin{array}{l}\text { United King- } \\
\text { dom }\end{array}$ & $-5,5 \%$ & $-1,1 \%$ & $-1,2$ \\
\hline Switzerland & $-3,7 \%$ & $-0,8 \%$ & $-0,1$ \\
\hline G3 Group & $-3,0 \%$ & $-0,6 \%$ & $-6,2$ \\
\hline Total & $\mathbf{- 3 , 2 \%}$ & $\mathbf{- 0 , 7 \%}$ & $-\mathbf{7 , 5}$ \\
\hline
\end{tabular}

Source: based on Institute of International Finance, The Cumulative Impact on the Global Economy of Changes in the Financial Regulatory Framework, Washington 2011, p.11.

The reports conducted by the International Monetary Fund highlight the varying impact of new regulations on individual countries, resulting from the level of economic development. The relatively large decrease in the amount of granted loans can be expected in countries such as: Denmark and Japan, and less in the United States. Generally the estimated increase for granting loans will be by 16 basis points, which will cause a decrease in rate of change of loans by $1.3 \%$ in the long term ${ }^{29}$.

Studies on the effects of the regulation were carried out also by the European Union. They calculated that the increase in the capital adequacy ratio of banks by one percentage point in the euro area will increase lending rates by 12 basis points in the long term, which is translated into a decline in GDP by 25 basis points over eight years and 36 basis points in the long term $^{30}$

In the face of such a wide variety of test results is difficult to assess the impact of new regulations on economic growth. Due to the differences when adopting and creating various sce-

${ }^{28}$ Institute of International Finance, The Cumulative Impact on the Global Economy of Changes in the Financial Regulatory Framework, Washington 2011, p. 11.

${ }^{29}$ T.F. Cosimano, D.S. Hakura, Bank Behavior in Response to Basel III: A Cross-country Analysis, "IMF Working Papers" 2011, WP/11/19.

${ }^{30}$ European Commission, Economic Impact of Changes in Capital Requirements in the Euro-area Banking sector, "Quarterly Report on the Euro Area" 2011/1. 
narios and assumptions, analysis that were obtained are practically incomparable with each other. However, following the quantitative criterion, the negative correlation between the new regulations and economic growth can be determined

\section{IMPLICATIONS OF NEW PRUDENTIAL REGULATION IN THE BANKING SECTOR WHICH STIMULATE GROWTH IN POLAND}

It is not possible to directly transfer the conclusions drawn from studies conducted in the world for the Polish market. When assessing the implications of the new prudential regulations for the domestic, the conditions and prospects of development of the Polish banking sector should be taken into consideration. Despite the undoubted growth of financial integration, also taking place in the area of banking services ${ }^{31}$, Polish banking sector has many specific features. There are many indications that banks in the countries of Central and Eastern Europe are less affected by the previous crisis than banks from developed countries ${ }^{32}$. In should be noted that lower banking penetration ratio in Polish Economy has different mode of actions in the banks. Until recently, banks operating on the Polish market have a surplus on economic capital surplus over regulatory capital. The introduction of new legislation on capital adequacy of banks and inhibited activity did not result in a sharp increase in held capital and sometimes lead to a reduction in the surplus. However, the new capital regulations may significantly affect the changes in the capital requirements for specific areas and encourage banks to changes its activity different areas of operations. ${ }^{33}$ Presumably, the development of the Polish banking sector will determine access to finance. It may be difficult because of possible occurrence of shortage of free capital on a global scale and the perception of the smaller markets, and thus Polish, as more risky and less reliable. ${ }^{34}$

For Polish market researched were conducted by Financial Supervision Commission to investigate changes in economic growth under influence of Basel III regulation. The study showed that the increase in average capital adequacy ratio may lead to a moderate increase in interest rates on loans and a slight decline in GDP growth. Increase in the capital adequacy ratio by 2.5 percentage points will result in compliance with the study over the next four years, growth in consumer lending rates by 0.56 percentage points and housing by 0.42 percentage points, which means a decrease in demand for housing loans by approximately $7.7 \%, 3.6 \%$ consumer and least - corporate loans by $0.07 \%$. These changes should result in a decrease in consumption and investment, it is projected that there will be a decline in consumer demand

\footnotetext{
${ }^{31}$ European Central Bank, Financial Integration in Europe, 2014.

${ }^{32}$ E. Miklaszewska, K. Mikołajczyk, M. Pawłowska, Post-crisis Regulatory Architecture and Central and East European Banks, ,The National Economy” 2013, p. -8.

${ }^{33}$ G. Szymańska, Impact of the development on the capital adequacy regulations for safety, activity and effectiveness of banks, "Safe Bank" 2011/4.

${ }^{34}$ E. Miklaszewska, Banki na rynku finansowym: problemy skali, efektywności i nadzoru, Wolters Kluwer Polska, Warszawa 2010, p. 40 .
} 
during this period by $20 \%$ and $6 \%$ of the investment. The result allow to expect a decline in GDP of $8 \%$ over 4 years. ${ }^{35}$. These relationships are shown in table below.

Table 2. Effect of growth capital adequacy ratio by 2.5 percentage points to the basic macroeconomic parameters

\begin{tabular}{|l|r|r|r|r|}
\hline \multirow{2}{*}{} & \multicolumn{5}{|c|}{ Subsequent years of simulation } \\
\cline { 2 - 5 } & $\mathbf{1}$ & \multicolumn{4}{|c|}{$\mathbf{2}$} & \multicolumn{1}{c|}{$\mathbf{3}$} & \multicolumn{1}{c|}{$\mathbf{4}$} \\
\cline { 2 - 5 } & \multicolumn{5}{|c|}{ In percentage points } \\
\hline The CPI inflation (y / y) & 0,00 & $-0,01$ & $-0,02$ & $-0,02$ \\
\hline GDP (y / y) & 0,00 & $-0,01$ & $-0,04$ & $-0,03$ \\
\hline Corporate loan & \multicolumn{5}{|c|}{ In percentages } \\
\hline Consumer loan & 0,00 & $-0,01$ & $-0,03$ & $-0,07$ \\
\hline Mortgage loan & $-0,19$ & $-1,48$ & $-2,83$ & $-3,64$ \\
\hline Overall loan & $-3,85$ & $-7,81$ & $-8,25$ & $-7,67$ \\
\hline Capital expenditure & $-0,67$ & $-1,83$ & $-2,48$ & $-2,95$ \\
\hline GDP & 0,00 & 0,00 & $-0,03$ & $-0,06$ \\
\hline
\end{tabular}

Source: based on P. Wdowiński, Makroekonomiczne skutki wyższych standardów kapitałowych: Analiza symulacyjna dla Polski, Komisja Nadzoru Finansowego, Warszawa 2011, p. 21.

An independent study on the impact of Basel III and CRD IV/CRR for banks was conducted by Marcinkowska, Wdowiński, Flejterski, Bukowski i Zygierewicz36. The analysis confirmed the results of previous studies. That study used 2 econometric models - The single panel model and interdependent multi-equation simulation model (macro-econometric). Both models have shown a positive and statistically significant effect of the solvency ratio, liquidity ratios and on level of interest rates on loans.In the panel model the attention is drawn to differences in sensitivity changes in the capital and liquidity requirements for a group of large banks and other banks ${ }^{37}$. Influence of changes in WIBOR on interest rate of credit provided by large banks is lower than in smaller banks. Taking into account when the criteria adopted in the research division of large banks and others, the first group represented $65 \%$ of the total. It can be concluded that the results which were obtained have relatively high importance.

The entire macroeconometric analysis was performed assuming a growth capital adequacy ratio in the banking sector by 4 percentage points and liquidity ratios M2 and M4 by 50 per-

${ }^{35}$ P. Wdowiński, Makroekonomiczne skutki wyższych standardów kapitałowych: Analiza symulacyjna dla Polski, Komisja Nadzoru Finansowego, Warszawa 2011, p. 21.

${ }^{36}$ M. Marcinkowska, P. Wdowiński, S. Flejterski, S. Bukowski, M. Zygierewicz, op. cit., s. 144-146.

37 Banks were assigned to the "big banks" or "other banks" based on the average value of assets. The division of the panel relied on the assumption that the share of the average assets of large banks (in the sample) was greater than $5 \%$. Mean values were calculated on the basis of the available number of observations in the period 1997-2011. The total share of the large banks in the sector was $65 \%$. 
centage points for a long period of time. The research shows that increasing capital and liquidity requirements in the Polish banking sector as a result of the adoption of Basel III solutions and CRD IV / CRR will reduce the level of GDP and economic growth. The decline in GDP growth is associated with a decrease in consumption, investment and lending. Limiting the number of loans is expected to be mainly in the area of housing loans. Downturn may be accompanied by depletion of deposits, which in the long term contributes to the deterioration of liquidity in the banking system. As a result, you can expect an increase in the amount of nonperforming loans and the deterioration in the labor market. In terms of numbers, these results are presented in Table 3

Table 3. The effect of increase, in the capital adequacy ratio by 4 percentage points and liquidity ratios M2 and M4 by 50 percentage points on the basic macroeconomic parameters

\begin{tabular}{|c|c|c|c|c|}
\hline & \multicolumn{4}{|c|}{ Subsequent years of simulation } \\
\hline & 1 & 2 & 3 & 4 \\
\hline & \multicolumn{4}{|c|}{ In percentage points } \\
\hline GDP $(y / y)$ & $-0,05$ & $-0,37$ & $-0,31$ & $-0,16$ \\
\hline \multirow[t]{2}{*}{ Unemployment rate } & 0,01 & 0,09 & 0,22 & 0,28 \\
\hline & \multicolumn{4}{|c|}{ In percentages } \\
\hline GDP & $-0,05$ & $-0,42$ & $-0,73$ & $-0,53$ \\
\hline Corporate deposit & $-0,21$ & $-1,40$ & $-2,02$ & $-0,38$ \\
\hline Household deposit & 0,00 & $-0,14$ & $-0,65$ & $-1,06$ \\
\hline Corporate loan & $-0,07$ & $-1,26$ & $-2,08$ & $-2,35$ \\
\hline Consumer loan & 0,00 & $-0,80$ & $-2,20$ & $-3,41$ \\
\hline Morgage loan & 0,00 & $-5,64$ & $-9,35$ & $-9,67$ \\
\hline Total loans & $-0,02$ & $-2,86$ & $-4,69$ & $-5,12$ \\
\hline
\end{tabular}

Source: Based on: M. Marcinkowska, P. Wdowiński, S. Flejterski, S. Bukowski, M. Zygierewicz, Wpływ regulacji sektora bankowego na wzrost gospodarczy - wnioski dla Polski, Narodowy Bank Polski, „Materiały i Studia” 2014, 305, p. 180.

\section{CONCLUSIONS}

The conducted analysis tried to show the possible impact of introducing new prudential regulations and how they impact development of economy. Results of the studies which focused on changes on the economy and the banking system analyzed by different institutions often led to divergent conclusions. Please note that all of them were carried out using a large number of assumptions, so the results should be treated with caution.

Most of the studies we can conclude that there is a real, however unknown possibility to slow down economic growth, moreover the analysis of the Basel Committee on Banking Supervision show that new rules will help to achieve high enough level of stability in the financial markets and this should stimulate growth.All other studies contradict this thesis. The most 
expected result of the new regulations that the demand of banks for equity will increase. Threat to the stability of the financial system will create pressure, which leads to solutions which are mainly aimed at strengthening the security of banks and increase the possibility of absorption by the effects of shocks that have arisen as a result of financial and economic crises. However, the development of new standards includes a lacking wider aspects of economy.

The results for Poland are consistent with the results of studies, for more developed economies. Also in relation to our country, inhibit of economic growth is expected. Polish situation is more difficult in comparison with other economies, because decision-makers in these cases are outside the borders of our country, and the influence of Polish Institutions that shape the regulations is very limited. It can be stated that supervisory authorities more often call it "Home bias", When solving global problems, their attention is based on minimizing consequences for the domestic market, even if it causes expenses for such banks in different countries.

Very often new regulations are based on the analysis of phenomena that do not exist on the Polish market, or are not important. The high level of control for Polish banking system by foreign capital has fair significance. Potential scenarios for banks to adjust to the new rules will depend on macroeconomic conditions, on their individual situation and conditions in the group in which have to operate. As a result of all these considerations, it can be concluded that there are no universal and timeless solutions that can be applied to all countries. There is also concern that the use of the new prudential norms will not lead to achieving the desired effects. Therefore there are questions about the desired degree of regulation, its scope and scale, as well as how long the standards should be maintained.

\section{REFERENCES}

[1] Angelini P., Clerc L., Cúrdia V., Cambacorta L., Gerali A., Locarno A., Motto R., Roeger V., van den Heuvel S., Vlček J., Basel III: Long-term Impact Economic Performance and Fluctuations, "Federal Reserve Bank of New York Staff Reports" 2011/485.

[2] Basel Committee on Banking Supervision, Results of the Comprehensive Quantitative Impact Study, Bank for International Settlements, Basel 2010.

[3] Basel Committee on Banking Supervision, Basel III: A Global Regulatory Framework for More Resilient Banks and Banking Systems - Revised Version, Bank for International Settlements, Basel 2011.

[4] Basel Committee on Banking Supervision, Basel III: The Liquidity Coverage Ratio and Liquidity Risk Monitoring Tools, Bank for International Settlements, Basel 2013.

[5] Cosimano T.F., Hakura D.S., Bank Behavior in Response to Basel III: A Cross-country Analysis, "IMF Working Papers" 2011, WP/11/19.

[6] Dyrektywa Parlamentu Europejskiego i Rady 2013/36/UE z 26 czerwca 2013 r. w sprawie warunków dopuszczenia instytucji kredytowych do działalności oraz nadzoru ostrożnościowego nad instytucjami kredytowymi i firmami inwestycyjnymi, zmieniająca dyrektywę 2002/87/WE i uchylająca dyrektywy 2006/48/WE oraz 2006/49/WE, OJ L 176.338 (CRD IV).

[7] European Banking Federation, Principles for a Successful Future of Banking in Europe, Brussels 2010.

[8] European Commission, European Financial Stability and Integration, Brussels 2014.

[9] European Central Bank, Financial Integration in Europe, 2014. 
[10] Elliott D.J., Quantifying the Effects of Lending Increased Capital Requirements, Brookings Institution 2009, www.brookings.edu/ /media/research/files/papers/2009/9/24\%20capital\%20elliott/ 0924_capital_elliott.pdf (last viewed 19.09.2014).

[11] Elliott D.J., A Further Exploration of Bank Capital Requirements: Effects of Competition from other Financial Sectors and Effects of Size of Bank or Borrower and of Loan Type, Brookings Institution 2010, http://www.brookings.edu/ /media/research/files/papers/2010/1/29\%20capital\%20 elliott/0129_capital_requirements_elliott.pdf (last viewed 19.09.2014).

[12] European Commission, Economic Impact of Changes in Capital Requirements in the Euro-area Banking Sector, "Quarterly Report on the Euro Area" 2011/1.

[13] Gafrikova V., Milic-Czerniak R., Bazylea III - zmiany kapitałowe i ich konsekwencje, „Bezpieczny Bank" 2011/4.

[14] Gemzik-Salwach A., Skutki regulacji Bazylei III dla sektora bankowego i gospodarki, „Annales Universitatis Mariae Curie-Skłodowska. Sectio H. Oeconomia" 2012/26.

[15] Hannoun H., The Basel III Capital Framework: A Decisive Breakthrough, Bank for International Settlements, Hong Kong 2010.

[16] Institute of International Finance, The Cumulative Impact on the Global Economy of Changes in the Financial Regulatory Framework, Washington 2011.

[17] Kalicki K., Wptyw Bazylei III/CRD4 na sytuacje sektora bankowego, 2014, http://alterum.pl/pdf/Dr_hab_Krzysztof_Kalicki.pdf (last viewed 19.09.2014).

[18] Karkowska R., Koszty ekonomiczne ryzyka systemowego na rynku finansowym, „Problemy Zarządzania" 2012/4.

[19] King M.R., Mapping Capital and Liquidity Requirements to Bank Lending Spreads, "BIS Working Papers" 2010/324

[20] Kochaniak K., Kapitat regulacyjny sektora bankowego w Polsce na tle rozwiazań Bazylei III, „Zeszyty Naukowe. Polskie Towarzystwo Ekonomiczne” 2011/11.

[21] Kornasiewicz A., Halesiak A., Konsekwencje kryzysu w strefie euro dla polskiego i europejskiego sektora bankowego, Głos w e-debacie zorganizowanej przez Instytut Badań nad Gospodarka Rynkową 2011.

[22] MAGG, Assessing the Macroeconomic Impact of the Transition to Stronger Capital and Liquidity Requirements - Final Report, Bank for International Settlements, Basel 2010.

[23] Marcinkowska M., Wdowiński P., Flejterski S., Bukowski S., Zygierewicz M., Wptyw regulacji sektora bankowego na wzrost gospodarczy - wnioski dla Polski, Narodowy Bank Polski, ,Materiały i Studia” 2014/305.

[24] Miklaszewska E., Mikołajczyk K., Pawłowska M., Post-crisis Regulatory Architecture and Central and East European Banks, „Gospodarka Narodowa” 2013/7-8.

[25] Miklaszewska E., Duże banki w świetle pokryzysowej architektury regulacyjnej, [in:] ed. I. Pyka, J. Cichorska , Finanse w niestabilnym otoczeniu - dylematy $i$ wyzwania. Bankowość. Wydawnictwo Uniwersytetu Ekonomicznego w Katowicach, Katowice 2012.

[26] Miklaszewska E., Banki na rynku finansowym: problemy skali, efektywności i nadzoru, Wolters Kluwer Polska, Warszawa 2010.

[27] Narodowy Bank Polski, Opinia NBP w sprawie dokumentu konsultacyjnego Komisji Europejskiej „Possible Further Changes to Capital Requirements Directive”, Warszawa 2010.

[28] Olszak M., Polityka ostrożnościowa w ujęciu makro, „Problemy Zarządzania” 2012/4.

[29] Przychodzeń J., Europejskie rynki finansowe w obliczu globalnego kryzysu, „Problemy Zarządzania" 2012/4.

[30] Rosati D.K., Regulacje makroostrożnościowe a stabilność sektora bankowego, „Bank i Kredyt” $2014 / 45$. 
[31] Rozporządzenie Parlamentu Europejskiego i rady (UE) nr 575/2013 z 26 czerwca 2013 r. w sprawie wymogów ostrożnościowych dla instytucji kredytowych i firm inwestycyjnych, zmieniające rozporządzenie (UE) nr 648/2012, OJ L 176.1 (CRR).

[32] Ruthenberg D., Landskroner Y., Loan Pricing under Basel II in an Imperfectly Competitive Banking Market, "Journal Banking \& Finance" 2008/12.

[33] Slovik P., Cournède B., Macroeconomic Impact of Basel III, OECD Economics Department Working Papers 2011.

[34] Szok regulacyjny a konkurencyjność i rozwój sektora bankowego, ed. S. Kasiewicz, L. Kurkliński, Warszawski Instytut Bankowości, Warszawa 2012.

[35] Szymańska G., Wpływ rozwoju regulacji dotyczacych adekwatności kapitałowej na bezpieczeństwo, aktywność i efektywność banków, „Bezpieczny Bank” 2011/4.

[36] Szymański K., Konsekwencje kryzysu zadtużenia w strefie euro dla europejskiego i polskiego sektora bankowego, referat wprowadzający Instytutu Badań nad Gospodarką Rynkową do edebaty, 2011.

[37] Wdowiński P., Makroekonomiczne skutki wyższych standardów kapitałowych: Analiza symulacyjna dla Polski, Komisja Nadzoru Finansowego, Warszawa 2011.

\section{MAKROEKONOMICZNE KONSEKWENCJE NOWYCH REGULACJI OSTROŻNOŚCIOWYCH W SEKOTRZE BANKOWYM}

W artykule przedstawiono wpływ nowych regulacji ostrożnościowych na rozwój sektora bankowego i tempo wzrostu PKB. Analizą objęto przede wszystkim regulacje związane z wprowadzeniem Bazylei III i CRD IV / CRR. Celem artykułu są przegląd dotychczasowych badań w tym zakresie i próba uporządkowania wniosków płynących z dotychczasowych rozważań. Jak dotąd wyniki badania wpływu nowych regulacji na gospodarkę i system bankowy często prowadziły do różnych wniosków, co uzasadnia potrzebę gromadzenia i porównywania tych wyników. Jednak należy zauważyć, że porównywanie takich badań jest trudne ze względu na różne założenia, które są dokonywane. Głównym celem pracy była ocena wpływu nowych regulacji ostrożnościowych na funkcjonowanie sektora bankowego. Ponadto omówiono kanały transmisji, przez które nowe przepisy przekładają się na tempo wzrostu gospodarczego i inne wskaźniki makroekonomiczne. Przeprowadzono analizę wpływu tych zmian zarówno w odniesieniu do gospodarki krajowej, jak i światowej. Uzyskane wyniki prowadzą do konkluzji, że wprowadzenie nowych regulacji doprowadzi do nieznacznego spadku przyszłego wzrostu gospodarczego. W związku z tym pojawiają się pytania dotyczące pożądanego stopnia regulacji, jej zakresu, skali i czasu utrzymania.

Słowa kluczowe: sektor bankowy, wzrost gospodarczy, Bazylea III, regulacje kapitałowe i płynnościowe

\section{DOI: 10.7862/rz.2015.mmr.9}

Tekst złożono w redakcji: styczeń 2015

Przyjęto do druku: marzec 2015 